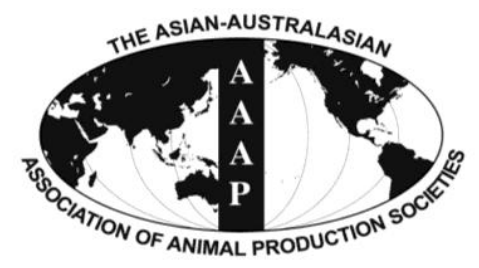

Asian-Aust. J. Anim. Sci.

Vol. 25, No. 6 : 852 - 860

June 2012

www.ajas.info

http://dx.doi.org/10.5713/ajas.2011.11501

\title{
Partial Characterization of $\alpha$-Galactosidic Activity from the Antarctic Bacterial Isolate, Paenibacillus sp. LX-20 as a Potential Feed Enzyme Source
}

\author{
Inkyung Park, Jaekoo Lee and Jaiesoon Cho* \\ Department of Animal Sciences and Environment, College of Animal Bioscience and Technology, \\ Konkuk University, Seoul 143-701, Korea
}

\begin{abstract}
An Antarctic bacterial isolate displaying extracellular $\alpha$-galactosidic activity was named Paenibacillus sp. LX-20 based on 16S rRNA gene sequence analysis. Optimal activity for the LX-20 $\alpha$-galactosidase occurred at pH $6.0-6.5$ and $45^{\circ} \mathrm{C}$. The enzyme immobilized on the smart polymer Eudragit L-100 retained $70 \%$ of its original activity after incubation for 30 min at $50^{\circ} \mathrm{C}$, while the free enzyme retained $58 \%$ of activity. The enzyme had relatively high specificity for $\alpha$-D-galactosides such as $p$-nitrophenyl- $\alpha$ galactopyranoside, melibiose, raffinose and stachyose, and was resistant to some proteases such as trypsin, pancreatin and pronase. Enzyme activity was almost completely inhibited by $\mathrm{Ag}^{+}, \mathrm{Hg}^{2+}, \mathrm{Cu}^{2+}$, and sodium dodecyl sulfate, but activity was not affected by $\beta$-mercaptoethanol or EDTA. LX-20 $\alpha$-galactosidase may be potentially useful as an additive for soybean processing in the feed industry. (Key Words: Antarctic, Paenibacillus sp. $\alpha$-Galactosidase, Feed Industry)
\end{abstract}

\section{INTRODUCTION}

Soybean meal (SBM) is the main protein supplement for poultry and livestock feed worldwide (Ghazi et al., 2003; Stein et al., 2008) and comprises over 50\% of the global protein sources in poultry and livestock feed (Kohlmeier, 1990). Moreover, SBM galactooligosaccharides have contributed to improving intestinal health of animals by increasing concentrations of beneficial gut bacteria including bifidobacteria and lactobacilli, as well as concentrations of short-chain fatty acids, which might be a potential alternative for subtherapeutic antibiotic supplementation (Smiricky-Tjardes et al., 2003). However, SBM $\alpha$-galactooligosaccharides such as raffinose (galactose- $\alpha-1,6$-sucrose), and stachyose (galactose- $\alpha-1,6-$ raffinose) which constitute about $1 \%$ and $6 \%$ on dry matter basis, respectively (Grieshop et al., 2003), act as antinutritive factors that may depress animal performance (Anderson and Wolf, 1995). The oligosaccharides appear to increase viscosity of digesta, hindering the digestion of nutrients by reducing their interaction with digestive

\footnotetext{
* Corresponding Author: Jaiesoon Cho. Tel: +82-2-450-3375, Fax: +82-2-455-1044, E-mail: chojs70@konkuk.ac.kr Submitted Dec. 23, 2011; Accepted Feb. 17, 2012; Revised Mar. 5, 2012
}

enzymes in the small intestine (Smits and Annison, 1996). Since monogastric animals including humans have very limited inherent $\alpha$-galactosidase (EC 3.2.1.22, $\alpha$-Dgalactoside galactohydrolase), which is essential to hydrolyze $\alpha$-galactosidic linkages in the aforementioned sugars, they are transferred intact into the large intestine, where anaerobic bacteria ferment them and lead to intestinal disturbances such as flatulence (Falkoski et al., 2006; Yoon and Hwang, 2008). Therefore, the reduction of these oligosaccharides in SBM by microbial $\alpha$-galactosidase treatment can potentially improve the nutritive value of SBM and likely helps to improve the production performance of the animals fed SBM-containing diets (Ghazi et al., 2003; Falkoski et al., 2006; Ao et al., 2009).

Microorganisms are the most attractive sources for industrial enzyme production (Syed et al., 2009). Microbially-enhanced feed production has greatly benefited from biotechnological approaches (Hasan et al., 2006). Many microbial $\alpha$-galactosidases have been extensively studied regarding their enzymatic properties and the genes encoding $\alpha$-galactosidases have been cloned (Fridjonsson et al., 1999; Yoon and Hwang, 2008). However, little is known of the $\alpha$-galactosidic activity of Paenibacillus sp., which has been regarded as an attractive source for producing 
carbohydrate degrading enzymes such as cellulase, xylanase, and $\beta$-glucosidase (Shipkowski and Brenchley, 2005; Kim et al., 2009; Waeonukul et al., 2009). The purpose of this study was to explore the partial catalytic properties of $\alpha$-galactosidic activity from an Antarctic bacterial isolate, Paenibacillus sp. LX-20, as a potential feed enzyme source.

\section{MATERIALS AND METHODS}

\section{Bacterial strain and culture conditions}

LX-20 derived from Antarctic soil samples was supplied by the Korea Polar Research Institute operating the King Sejong Station (South Korea) in Antarctica. Screening for $\alpha$-galactosidase activity was performed by the appearance of blue colonies on selective Luria Bertani (LB) agar ( $\mathrm{pH}$ 7.2) supplemented with $0.2 \%$ lactose and $32 \mu \mathrm{g} / \mathrm{ml}$ of $5-$ bromo-4-chloro-3-indolyl- $\alpha$-D-galactopyranoside (X- $\alpha$ Gal) as previously described (Goulas et al., 2009) at $28^{\circ} \mathrm{C}$. Growth and $\alpha$-galactosidase production were investigated in an Erlenmeyer flask (2 L) containing $500 \mathrm{ml}$ of the enzyme production medium composed of Bacto tryptic soy broth (Difco) (1.7\% pancreatic digest of casein, $0.3 \%$ papaic digest of soybean, $0.25 \%$ dextrose, $0.5 \% \mathrm{NaCl}$, $0.25 \%$ dipotassium phosphate; $\mathrm{pH} 7.2$ ) and $0.3 \%$ soybean meal inoculated with $1 \%$ (vol/vol) $24 \mathrm{~h}$ inoculum at $28^{\circ} \mathrm{C}$ with vigorous shaking $(220 \mathrm{rpm})$ by monitoring the absorbance (O.D.600nm) and $\alpha$-galactosidase activity of the culture supernatant at various time points.

\section{Taxonomic identification of strain LX-20}

Genomic DNA was extracted from strain LX-20 using the FastDNA kit (Qbiogene) according to the manufacturer's protocol. The 16S rRNA gene was amplified from genomic DNA by PCR using the universal primers, 27F (5'-AGAGTTTGATCCTGGCTCAG-3') and 1492R (5'-GGTTACCTTGTTACGACTT-3') (William et al., 1991). The amplified 1,453 bp sequences were determined by an automated ABI PRISM 3730 XL DNA analyzer (Applied Biosystems). The resulting sequences were compared with the GenBank database (NCBI) using BLAST (Altschul et al., 1990). Sequences showing a relevant degree of similarity were imported into the CLUSTAL W program (Thompson et al., 1994) and aligned. The evolutionary distances with other strains of Paenibacilli were computed using the Maximum Composite Likelihood method (Tamura et al., 2004) and the phylogenetic relationships were determined using the software MEGA version 4.0 (Tamura et al., 2007).

\section{Partial purification of the enzyme}

Strain LX-20 was cultivated in $1 \mathrm{~L}$ of the enzyme production medium for $96 \mathrm{~h}$ at $28^{\circ} \mathrm{C}$. The culture medium containing secreted $\alpha$-galactosidase was centrifuged $\left(10,000 \times \mathrm{g} ; 30 \mathrm{~min} ; 4^{\circ} \mathrm{C}\right)$ to remove cells, and the protein in the supernatant was then precipitated with ammonium sulfate (50\% saturation). The pellet was dissolved in $50 \mathrm{mM}$ Tris- $\mathrm{HCl}(\mathrm{pH} 8.0)$ and dialyzed overnight against $50 \mathrm{mM}$ Tris- $\mathrm{HCl}(\mathrm{pH} 7.4)$ at $4{ }^{\circ} \mathrm{C}$. The dialyzed solution was used as the enzyme source to examine the catalytic properties throughout this work.

\section{Zymogram analysis}

The enzyme was subjected to non-denaturing $6.5 \%$ polyacrylamide gel electrophoresis (PAGE) using a Modular Mini-Protein II Electrophoresis System (Bio-Rad) according to the manufacturer's instructions. After gel electrophoresis, the gel was placed on $1.5 \%$ (wt/vol) bacto agar plate containing $4 \mathrm{mg} / \mathrm{ml} \mathrm{X}-\alpha-\mathrm{Gal}$ and was incubated at $40^{\circ} \mathrm{C}$ for $12 \mathrm{~h}$. The band of $\alpha$-galactosidase activity was detected by appearance of a blue zone.

\section{Enzyme assay and substrate specificity}

Unless otherwise stated, $\alpha$-galactosidase activity was measured at $40^{\circ} \mathrm{C}$ by assaying the release of $p$-nitrophenol from $p$-nitrophenyl- $\alpha$-D-galactopyranoside with a final concentration of $1 \mathrm{mM}$ in $1 \mathrm{ml}$ of $50 \mathrm{mM}$ sodium phosphate $(\mathrm{pH}$ 6.5). Activity on other $p$-nitrophenyl $(p \mathrm{NP})$ or $o$-nitrophenyl $(o \mathrm{NP})$ conjugated synthetic substrates such as $p$ NP- $\alpha$-L-arabinofuranoside, $\quad p$ NP- $\alpha$-D-glucopyranoside, $p$ NP- $\beta$-D-galactopyranoside, $\quad p$ NP- $\beta$-D-xylopyranoside, $p$ NP- $\beta$-D-cellobioside, $o$ NP- $\beta$-D-galactopyranoside, and $o \mathrm{NP}-\beta$-D-glucopyranoside was determined in $1 \mathrm{ml}$ of 50 $\mathrm{mM}$ sodium phosphate $(\mathrm{pH} 6.5)$ at $40^{\circ} \mathrm{C}$ with a final substrate concentration of $1 \mathrm{mM}$. The reactions were then stopped by the addition of $1 \mathrm{ml}$ of $1 \mathrm{M} \mathrm{Na}_{2} \mathrm{CO}_{3}$ and color development was measured at O.D. $405 \mathrm{~nm}$. One unit (U) of enzyme activity was defined as the amount of enzyme to produce $1 \mu \mathrm{mol}$ of $p$-nitrophenol or $o$-nitrophenol per minute under the assay conditions described. When maltose, carboxymethylcellulose (CMC), xylan, galactomannan and starch were used as the substrate with a final concentration of $0.4 \%$, the production of reducing sugar was determined under standard assay conditions by the dinitrosalicylic acid (DNS) method (Miller, 1959). Determination of activity against lactose, raffinose, melibiose, and stachyose was evaluated by assaying the release of D-galactose using a galactose test kit (Boehringer Mannheim $\mathrm{GmbH}$ ). One enzyme unit (U) was defined as the amount of enzyme to produce $1 \mu \mathrm{mol}$ of reducing sugar equivalent, or galactose per minute under the assay conditions.

\section{Effect of pH and temperature on enzyme activity}

$\alpha$-Galactosidase activities were investigated in the $\mathrm{pH}$ range of 3-9 (50 mM glycine- $\mathrm{HCl}(\mathrm{pH} 3) ; 50 \mathrm{mM}$ sodium 
acetate ( $\mathrm{pH} 4-5.5) ; 50 \mathrm{mM}$ sodium phosphate ( $\mathrm{pH}$ 5.5-7); $50 \mathrm{mM}$ Tris- $\mathrm{HCl}(\mathrm{pH} 7-9))$ at $30^{\circ} \mathrm{C}$ and temperatures between 0 and $80^{\circ} \mathrm{C}$ at the optimum $\mathrm{pH}$.

\section{Determination of protease resistance}

The stability of LX-20 $\alpha$-galactosidase to proteolysis was investigated as previously described (Cao et al., 2010) with slight modification. The partially purified enzyme was incubated with trypsin, pancreatin, proteinase $\mathrm{K}$, subtilisin Carlsberg or pronase (all from Sigma) at $37^{\circ} \mathrm{C}$ for $30 \mathrm{~min}$ in $0.1 \mathrm{M}$ sodium phosphate $(\mathrm{pH}$ 7.0), using a protease: $\alpha$-galactosidase (wt:wt) ratio of $1: 10$ and then subjected to enzyme activity assay under standard conditions.

\section{Effect of metal ions and chemicals on enzyme activity}

The effect of different metal ions and chemicals on $\alpha$-galactosidase activity was determined under standard assay conditions after the enzyme was pre-incubated in the presence of $1 \mathrm{mM}$ of $\mathrm{Mg}^{2+}, \mathrm{Ca}^{2+}, \mathrm{Co}^{2+}, \mathrm{Ni}^{2+}, \mathrm{Cu}^{2+}, \mathrm{Mn}^{2+}$, $\mathrm{Fe}^{2+}, \mathrm{Hg}^{2+}, \mathrm{Ba}^{2+}, \mathrm{Ag}^{+}, \mathrm{K}^{+}, \mathrm{Na}^{+}, \beta$-mercaptoethanol, EDTA, SDS, or PMSF (phenylmethylsulfonyl fluoride) in $50 \mathrm{mM}$ sodium phosphate $(\mathrm{pH} 6.5)$ for $20 \mathrm{~min}$ at $25^{\circ} \mathrm{C}$.

\section{Preparation of immobilized enzyme}

2\% (wt/vol) Eudragit L-100 (Rohm Pharma, Weiterstadt, Germany) solution was prepared as previously described (Roy et al., 2003). Partially purified LX-20 $\alpha$-galactosidase $(2.5 \mathrm{ml})$ was added to $0.75 \mathrm{ml}$ of the Eudragit L-100 solution and the final volume was made up to $5.0 \mathrm{ml}$ with $50 \mathrm{mM}$ sodium phosphate ( $\mathrm{pH} 6.5$ ). After incubation for $1 \mathrm{~h}$ at $25^{\circ} \mathrm{C}$, the polymer was precipitated by lowering the $\mathrm{pH}$ to 4.0 with $3 \mathrm{M}$ acetic acid. After $20 \mathrm{~min}$, the suspension was centrifuged at $12,000 \times \mathrm{g}$ for $20 \mathrm{~min}$. The pellet was washed with $4 \mathrm{ml}$ of $10 \mathrm{mM}$ sodium acetate $(\mathrm{pH} 4.0)$ and the suspension was again centrifuged. Finally, the pellet was suspended in $4 \mathrm{ml}$ of $50 \mathrm{mM}$ sodium phosphate ( $\mathrm{pH}$ 6.5) and used as the immobilized enzyme. As a reference, the stability of the enzyme at $\mathrm{pH} 4$ during immobilization process was monitored.

\section{Thermal stability}

Thermal stability of the LX-20 $\alpha$-galactosidase was estimated by incubation of the free enzyme or the immobilized enzyme in $50 \mathrm{mM}$ sodium phosphate $(\mathrm{pH}$ 6.5) for $30 \mathrm{~min}$ at various temperatures ranging from 30 to $80^{\circ} \mathrm{C}$ before measuring.

\section{RESULTS AND DISCUSSION}

Identification of isolated strain LX-20 and the $\alpha$-galactosidase production

To identify the isolated strain LX-20 showing

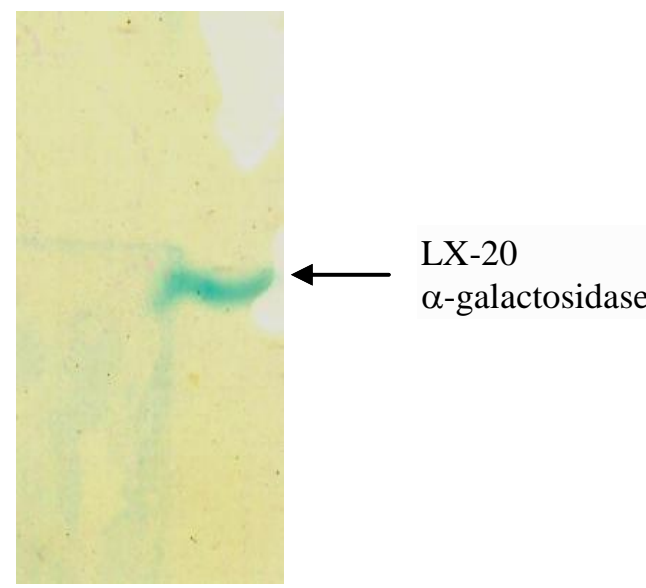

Figure 1. Zymogram analysis of $\alpha$-galactosidase activity in the enzyme preparation.

$\alpha$-galactosidase activity (Figure 1), the 16S rRNA gene was cloned and the sequence was compared with those available in the database. A phylogenic tree based on the 16S rRNA gene sequences from 11 Paenibacillus strains showed that strain LX-20 shared $99.1 \%$ sequence identity with the type strain, Paenibacillus odorifer DSM $15391^{\mathrm{T}}$ (Figure 2). Therefore, it was named Paenibacillus sp. LX-20.

Extracellular $\alpha$-galactosidase production by strain LX-20 was somewhat growth phase-dependent (Figure 3). During $\log$ phase of growth, little $\alpha$-galactosidase was secreted, but about 30-fold increase in extracellular $\alpha$-galactosidase activity was induced during transition to stationary phase of growth, reaching a maximum $(0.084 \pm 0.00019 \mathrm{U} / \mathrm{ml})$ at $36 \mathrm{~h}$ of incubation. Meanwhile, cell growth steeply increased after the initial $8 \mathrm{~h}$ of incubation and reached a peak $\left(4.35 \pm 0.03\right.$ of $\left.0 . \mathrm{D}_{600 \mathrm{~mm}}\right)$ at $28 \mathrm{~h}$ of incubation.

\section{Nucleotide sequence accession numbers}

The nucleotide sequence of the 16S rRNA gene has been deposited in the GenBank database under Accession No. HQ660810.

\section{Effect of pH on enzyme activity}

As shown in Figure 4A, the optimal activity for the LX$20 \alpha$-galactosidase occurred at $\mathrm{pH} 6.0-6.5$, and over $45 \%$ of the activity was achieved between $\mathrm{pH} 5.5$ and 7.0. The enzyme was nearly inactivated at acidic $\mathrm{pH}$ ranges ( 3 to 5), which characteristic of most bacterial $\alpha$-galactosidases (Leder et al., 1999; King et al., 2002; Patil et al., 2010), even though fungal and yeast $\alpha$-galactosidases generally display optimal activities in acidic conditions (Viana et al., 2006; Wang et al., 2010). In fact, the acidic $\alpha$-galactosidase is inappropriate for the removal of galactooligosaccharides in soymilk, which can be used as an economic partial substitute for whole milk in calf-raising facilities (Ghorbani 


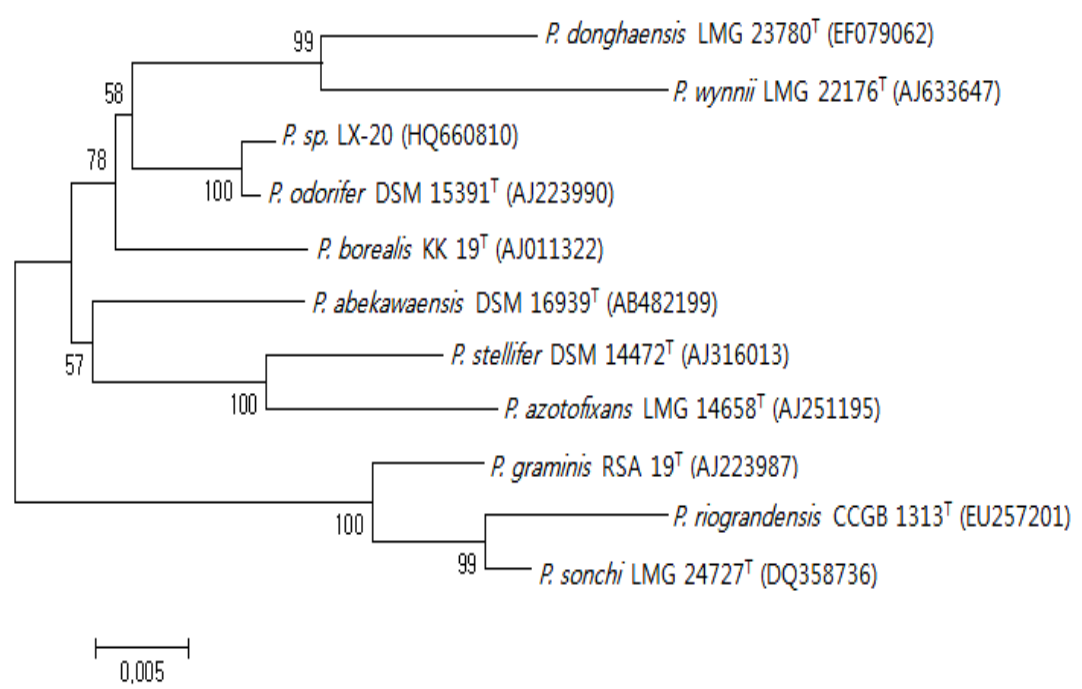

Figure 2. Phylogenic relationship of the 16S rRNA sequences of Paenibacillus sp. LX-20 with other type strains of Paenibacillus. Bootstrap values (based on 1,000 trials and only values $>50 \%$ ) are shown at the nodes. The GenBank accession numbers are indicated in parentheses. Bar denotes 5-base substitutions per 1,000 nucleotide position. $P$. is an abbreviation of Paenibacillus.

et al., 2007), because the natural $\mathrm{pH}$ of soymilk is 6.2 to 6.4 (Yoon and Hwang, 2008). Nevertheless, $\alpha$-galactosidase from a bacterial strain, Leuconostoc mesenteriodes JK55 can retain $70 \%$ of its maximal activity at $\mathrm{pH} 4.0$ (Yoon and Hwang, 2008).

\section{Effect of temperature on enzyme activity and thermal} stability

LX-20 $\alpha$-galactosidase showed optimal activity at $45^{\circ} \mathrm{C}$ and more than $55 \%$ of the highest activity remained at 30 to $45^{\circ} \mathrm{C}$ (Figure 4B), which is reminiscent of enzymes from mesophilic microbes. Generally, enzymes produced by microbes that dwell in cold environments display higher catalytic efficiency at low temperatures and greater thermosensitivity than their mesophilic counterparts (Gerday et al., 1997). For example, CelG from the Antarctic bacterium, Pseudoalteromonas haloplanktis, is a heat-labile cellulase and its half-life during incubation at $45^{\circ} \mathrm{C}$ is approximately 40 min (Garsoux et al., 2004). Meanwhile, a cold-active cellulase, CelG can be produced from the

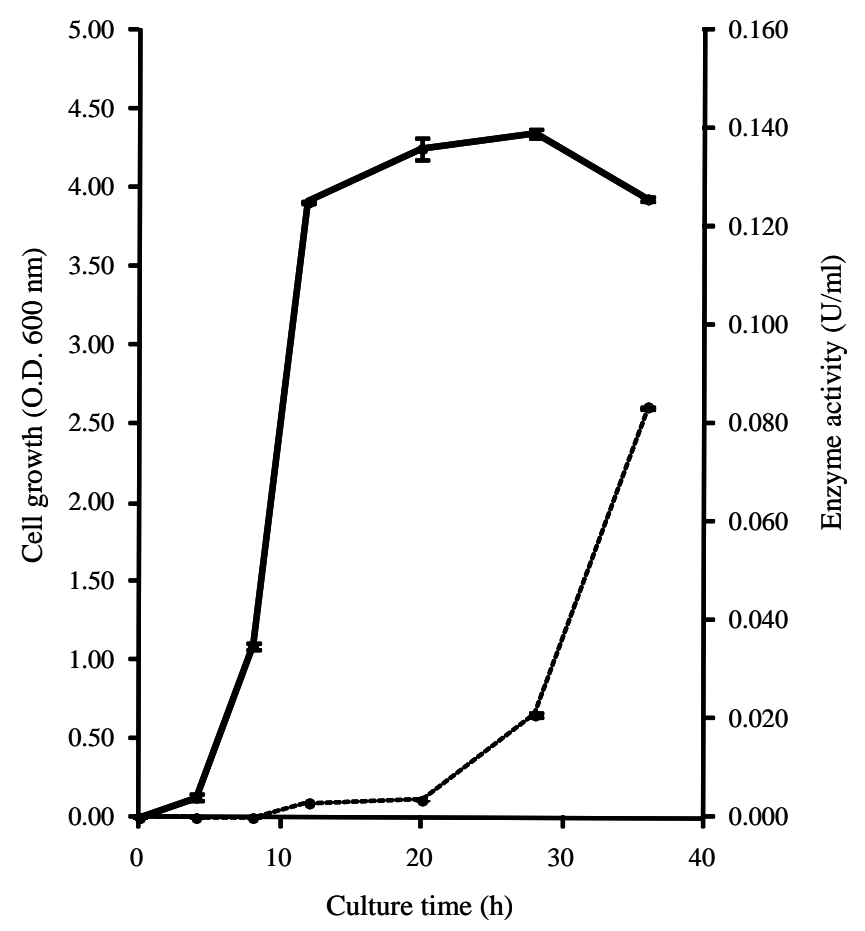

Figure 3. Growth and $\alpha$-galactosidase production by Paenibacillus sp. LX-20. Symbols represent $\alpha$-galactosidase activity (dotted line) and growth (solid line). Data were expressed as mean and standard errors from three experiments. 

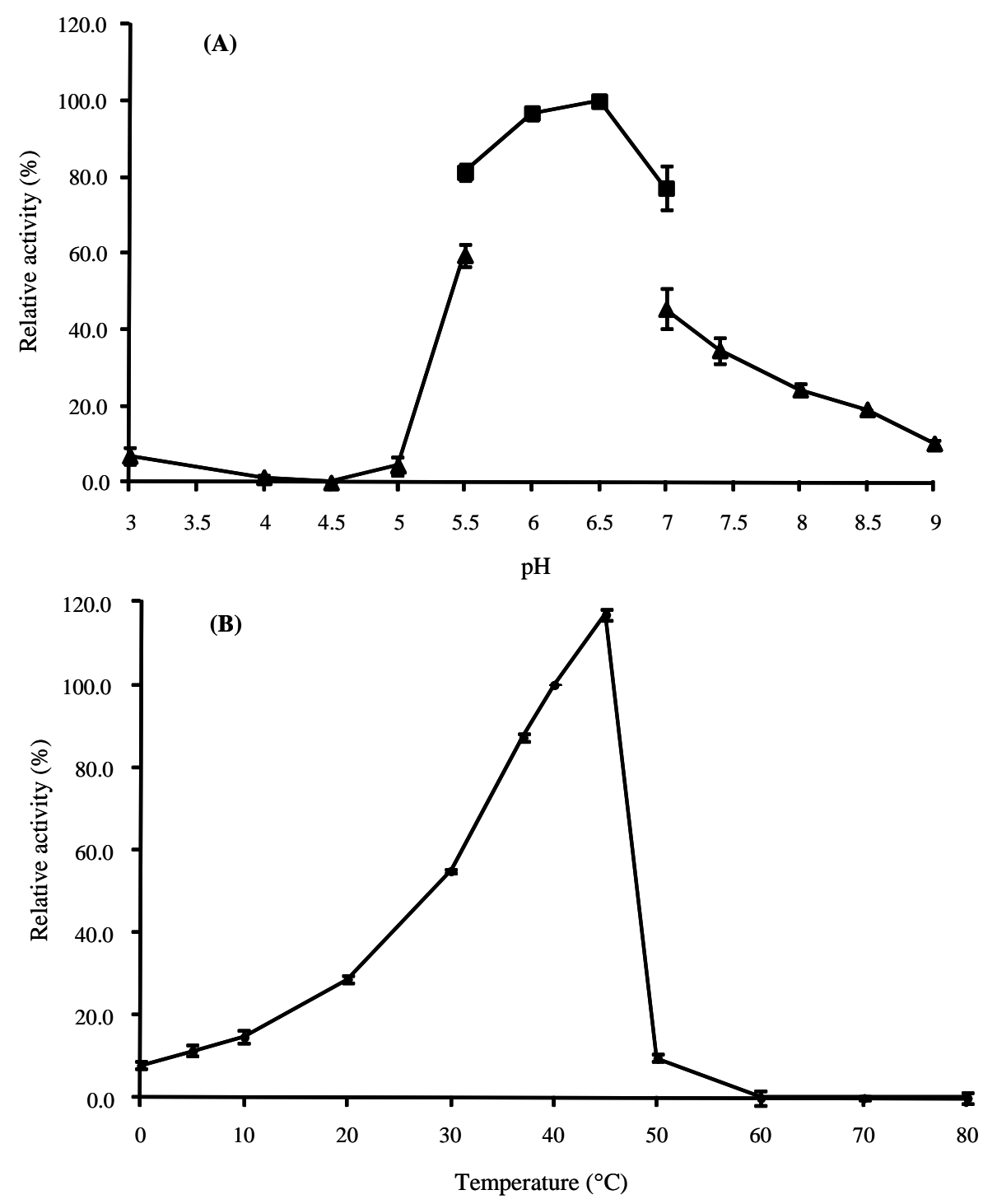

Figure 4. Optimal $\mathrm{pH}$ (A) and temperature (B) activity profiles. (A) Relative activity at $30^{\circ} \mathrm{C}$ and various pHs where $100 \%$ equates to $0.032 \pm 0.0011 \mathrm{U} / \mathrm{ml}$. Used buffers : $50 \mathrm{mM}$ glycine- $\mathrm{HCl}(\mathrm{pH} 3$ ) (closed triangle), $50 \mathrm{mM}$ sodium acetate (pH 4 to 5.5) (closed triangle), $50 \mathrm{mM}$ sodium phosphate ( $\mathrm{pH} 5.5$ to 7) (closed square), $50 \mathrm{mM}$ Tris- $\mathrm{HCl}$ (pH 7 to 9) (closed triangle) (B) Relative activity at pH 6.5 and various temperatures where $100 \%$ equates to $0.035 \pm 0.0003 \mathrm{U} / \mathrm{ml}$. The assays were performed at a final concentration of $1 \mathrm{mM} p$-Np- $\alpha$ galactopyranoside. Data were expressed as mean and standard errors from three experiments.

mesophilic ruminal anaerobe, Fibrobacter succinogenes S85, showing a temperature optimum of $25^{\circ} \mathrm{C}$ and complete inactivation even after $20 \mathrm{~min}$ of exposure at $50^{\circ} \mathrm{C}$ (Iyo and Forsberg, 1999). In fact, LX-20 $\alpha$-galactosidase may be suitable for the use of a feed supplement to poultry or swine diets because the optimal temperature range of enzyme is close to the intestinal temperature of the animals (37 to $40^{\circ} \mathrm{C}$ ) (Lei and Porres, 2003). LX-20 $\alpha$-galactosidase was successfully immobilized using Eudragit L-100 and the enzyme was stable at $\mathrm{pH} 4$ during the immobilization process (Figure 5). Even if the immobilization of LX-20 $\alpha$-galactosidase on the smart polymer Eudragit (Roy et al., 2003; Ai et al., 2005) had no remarkable effect on the thermal stability of the enzyme, the immobilized enzyme retained $70 \%$ of its original activity after incubation for 30 $\min$ at $50{ }^{\circ} \mathrm{C}$, while the corresponding activity of the free enzyme was only $58 \%$ (Figure 6 ).

\section{Effect of proteolysis on enzyme activity}

LX-20 $\alpha$-galactosidase showed different resistances to the tested proteases (Figure 7). The enzyme retained about $50 \%$ and $60 \%$ of its initial activity after 30 min incubation with proteinase $\mathrm{K}$ and subtilisin Carlsberg, respectively. However, trypsin, pancreatin and pronase had no effect on the enzymatic activity. The susceptibility of feed enzymes to proteolytic attack is important because the rate and site of inactivation of an enzyme are determined by this property (Wang et al., 2007). In contrast, the bacterial $\alpha$-galactosidase 


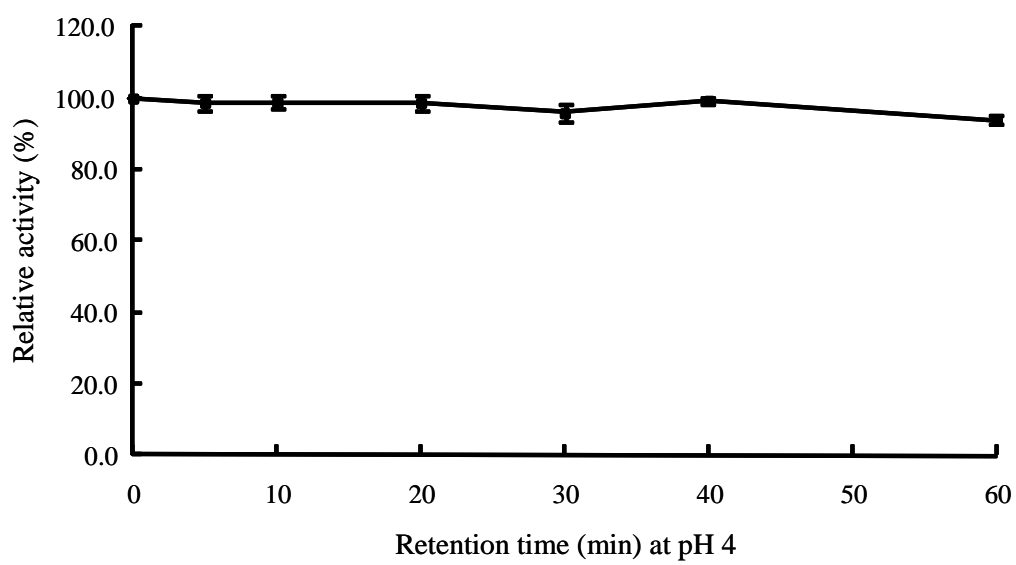

Figure 5. The stability of the LX-20 $\alpha$-galactosidase at $\mathrm{pH} 4$ during immobilization process. Data were expressed as mean and standard errors from three experiments.

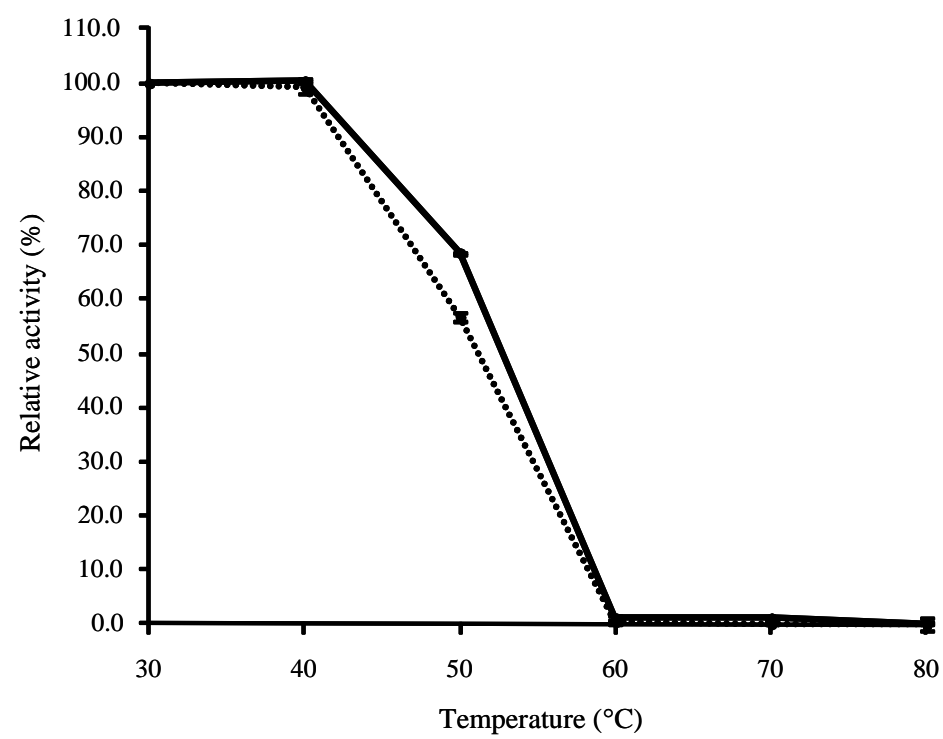

Figure 6. Temperature effects on the stability of the LX-20 $\alpha$-galactosidase. Symbols represent the free form enzyme (dotted line) and the immobilized form enzyme (solid line). Data were expressed as mean and standard errors from three experiments.

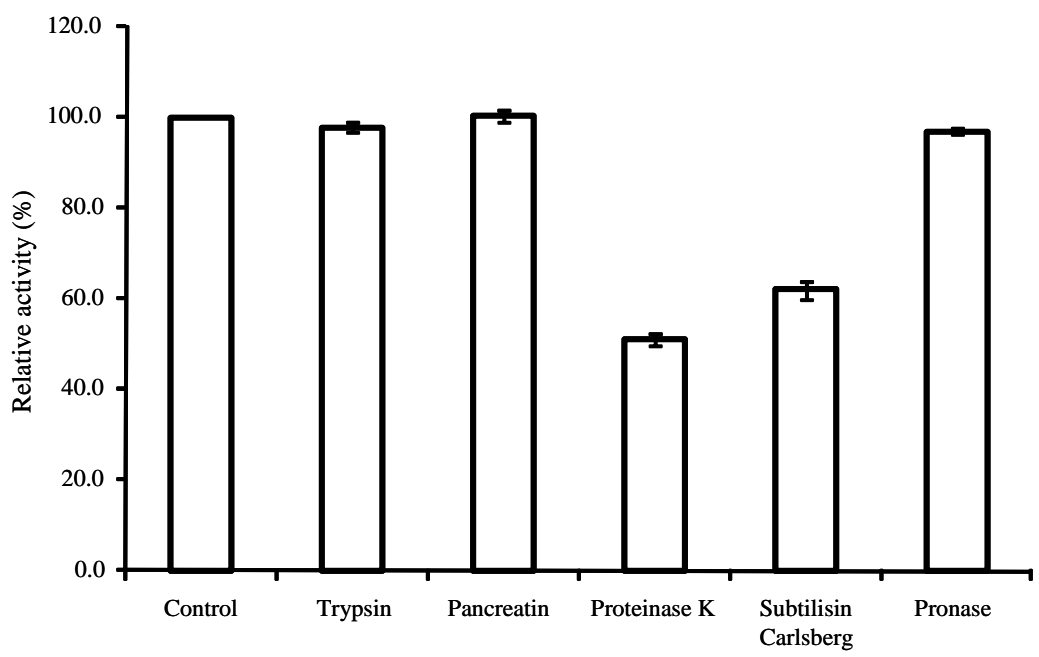

Figure 7. Effect of proteases on the LX-20 $\alpha$-galactosidase activity. The activity of protease-untreated control was defined as $100 \%$, which equates to $0.034 \pm 0.009 \mathrm{U} / \mathrm{ml}$. Data were expressed as mean and standard errors from three experiments. 
from Streptomyces sp. S27 loses about $50 \%$ of its initial activity after $30 \mathrm{~min}$ of trypsin digestion (Cao et al., 2010).

\section{Effect of metal ions and inhibitors on enzyme activity}

LX-20 $\alpha$-galactosidase was almost completely inhibited by $\mathrm{Ag}^{+}, \mathrm{Hg}^{2+}, \mathrm{Cu}^{2+}$, and SDS (Table 1). This is consistent with previous result reported for fungal $\alpha$-galacotsidase from Penicillium griseoroseum (Falkoski et al., 2006). The LX-20 $\alpha$-galactosidase appears to possess sensitive sulfhydryl groups in the active site, since $\mathrm{Ag}^{+}$and $\mathrm{Hg}^{2+}$ are strong thiol-specific inhibitors of several $\alpha$-galactosidases (King et al., 2002; Cao et al., 2010; Wang et al., 2010). The hypersensitivity of the enzyme to the common anionic detergent SDS also indicates that hydrogen bonds may play a pivotal role in maintaining the enzymatic activity (Wang et al., 2005). However, $\mathrm{Cu}^{2+}$ stimulated the activity of $\alpha$-galactosidase from an acidophilic fungus, Bispora $s p$. (Wang et al., 2010). $\mathrm{Ca}^{2+}, \mathrm{Co}^{2+}, \mathrm{Mn}^{2+}, \mathrm{Ba}^{2+}, \mathrm{Mg}^{2+}, \mathrm{Na}^{+}$, and $\mathrm{K}^{+}$had no major effects on the activity of LX-20 $\alpha$-galactosidase. The enzyme was not affected by $\beta$-mercaptoethanol and EDTA, suggesting that it may not be a metalloenzyme (Falkoski et al., 2006; Viana et al., 2006). Additionally, the enzyme was partially inhibited by $\mathrm{Fe}^{2+}$, and $\mathrm{Ni}^{2+}$, and the established serine protease inhibitor PMSF (Hutadilok-Towatana et al., 1999).

\section{Substrate specificity}

LX-20 $\alpha$-galactosidase activity against various substrates was summarized in Table 2. The enzyme was specific for the aryl- $\alpha$-galactosidic substrate, $p$-nitrophenyl-
Table 1. Effect of metal ions and chemicals on LX-20 $\alpha$ galactosidase activity

\begin{tabular}{lc}
\hline Reagent $^{\mathrm{a}}$ & Relative activity $(\%)^{\mathrm{b}}$ \\
\hline $\mathrm{No}$ addition & 100.0 \\
$\mathrm{Ca}^{2+}$ & $100.6 \pm 1.1$ \\
$\mathrm{Co}^{2+}$ & $84.1 \pm 1.6$ \\
$\mathrm{Fe}^{2+}$ & $74.3 \pm 1.1$ \\
$\mathrm{Mg}^{2+}$ & $101.3 \pm 2.1$ \\
$\mathrm{Mn}^{2+}$ & $85.8 \pm 2.3$ \\
$\mathrm{Ba}^{2+}$ & $89.1 \pm 0.7$ \\
$\mathrm{Cu}^{2+}$ & $1.9 \pm 1.8$ \\
$\mathrm{Ni}^{2+}$ & $34.5 \pm 0.6$ \\
$\mathrm{Hg}^{2+}$ & $17.0 \pm 4.0$ \\
$\mathrm{~K}^{+}$ & $96.6 \pm 0.2$ \\
$\mathrm{Na}^{+}$ & $99.1 \pm 0.9$ \\
$\mathrm{Ag}$ & 0.0 \\
$\beta-m e r c a p t o e t h a n o l$ & $110.0 \pm 0.8$ \\
EDTA & $102.3 \pm 0.3$ \\
$\mathrm{SDS}$ & $2.7 \pm 1.2$ \\
PMSF & $69.1 \pm 1.3$
\end{tabular}

${ }^{a}$ The final concentration of each reagent was $1 \mathrm{mM}$ in the assay buffer.

${ }^{\mathrm{b}} 100 \%$ was assigned to the activity in the absence of all reagents and equates to $0.037 \pm 0.0003 \mathrm{U} / \mathrm{ml}$. Data were expressed as mean and standard errors from three experiments.

$\alpha$-galactopyranoside. However, little or no activity was detected against maltose, lactose and other synthetic substrates containing $\beta$-linkages or containing arabinose and glucose residues. The enzyme showed no ability to hydrolyze polysaccharides such as carboxymethylcellulose,

Table 2. Substrate specificity of LX-20 $\alpha$-galactosidase

\begin{tabular}{lcc}
\hline Substrates & Concentration & Enzyme activity (U/mL) \\
\hline$p$-nitrophenyl- $\alpha$-D-galactopyranoside & $1 \mathrm{mM}$ & $0.033 \pm 0.001$ \\
$p$-nitrophenyl- $\beta$-D-galactopyranoside & $1 \mathrm{mM}$ & $0.002 \pm 0.0001$ \\
$p$-nitrophenyl- $\alpha$-D-glucopyranoside & $1 \mathrm{mM}$ & 0.000 \\
o-nitrophenyl- $\beta$-D-galactopyranoside & $1 \mathrm{mM}$ & 0.000 \\
$p$-nitrophenyl- $\beta$-D-xylopyranoside & $1 \mathrm{mM}$ & 0.000 \\
$p$-nitrophenyl- $\beta$-D-cellobioside & $1 \mathrm{mM}$ & 0.000 \\
o-nitrophenyl- $\beta$-D-glucopyranoside & $1 \mathrm{mM}$ & 0.000 \\
$p$-nitrophenyl- $\alpha$-L-arabinofuranoside & $1 \mathrm{mM}$ & $0.004 \pm 0.002$ \\
Raffinose & $1 \mathrm{mM}$ & $0.752 \pm 0.024$ \\
Melibiose & $1 \mathrm{mM}$ & $2.476 \pm 0.073$ \\
Stachyose & $1 \mathrm{mM}$ & $2.816 \pm 0.088$ \\
Lactose & $1 \mathrm{mM}$ & 0.000 \\
Carboxymethylcellulose (CMC) & $0.4 \%$ & 0.000 \\
Xylan (birchwood) & $0.4 \%$ & 0.000 \\
Galactomannan (locust bean gum) & $0.4 \%$ & 0.000 \\
Starch & $0.4 \%$ & 0.000 \\
Maltose & $0.4 \%$ & 0.000 \\
\hline
\end{tabular}

Data were expressed as mean and standard errors from three experiments. 
xylan, galactomannan (locust bean gum) and starch. Among the galacto-oligosaccharides tested, stachyose was most effectively hydrolyzed by the enzyme in comparison with raffinose or melibiose. In contrast, most $\alpha$-galactosidases degrade raffinose rapidly and stachyose slowly (Ishiguro et al., 2001). Many family $27 \alpha$-galactosidases catalyze the release of galactose from intact galactomannan polymers, whereas the substrate specificity in family 36 is restricted to small oligosaccharides including raffinose and stachyose (Wang et al., 2010). Thus, the LX-20 $\alpha$-galactosidase may belong to family 36 .

In conclusion, LX-20 $\alpha$-galactosidase may be potential for use as an additive for soybean processing in the feed industry, because the temperature and $\mathrm{pH}$ optima of the enzymatic activity are appropriate for the physiological surroundings and manufacturing conditions in soybean processing, and the enzyme showed high specificity for galacto-oligosaccharides, as well as resistance to some intestinal proteases. Future scientific studies including gene cloning, protein engineering, and downstream fermentation technology will focus on maximizing the catalytic efficiency and productive yield of the enzyme.

\section{ACKNOWLEDGEMENT} 2011 .

This paper was supported by Konkuk University in

\section{REFERENCES}

Ai, Z., Z. Jiang, L. Li, W. Deng, I. Kusakabe and H. Li. 2005. Immobilization of Streptomyces olivaceoviridis E-86 xylanase on Eudragit S-100 for xylo-oligosaccharide production. Process Biochem. 40:2707-2714.

Altschul, S. F., W. Gish, W. Miller, E. W. Myers and D. J. Lipman. 1990. Basic local alignment search tool. J. Mol. Biol. 215:403410.

Anderson, R. L. and W. J. Wolf. 1995. Compositional changes in trypsin inhibitors, phytic acid, saponins and isoflavones related to soybean processing. J. Nutr. 125:581S-588S.

Ao, T., A. H. Cantor, A. J. Pescatore, M. J. Ford, J. L. Pierce and K. A. Dawson. 2009. Effect of enzyme supplementation and acidification of diets on nutrient digestibility and growth performance of broiler chicks. Poult. Sci. 88:111-117.

Cao, Y., T. Yuan, P. Shi, H. Luo, N. Li, K. Meng, Y. Bai, P. Yang, Z. Zhou, Z. Zhang and B. Yao. 2010. Properties of a novel $\alpha$-galactosidase from Streptomyces sp. S27 and its potential for soybean processing. Enzyme Microb. Technol. 47:305-312.

Falkoski, D. L., V. M. Guimaraes, C. M. Callegari, A. P. Reis, E. G. De Barros and S. T. De Rezende. 2006. Processing of soybean products by semipurified plant and microbial $\alpha$-galactosidases. J. Agric. Food Chem. 54:10184-10190.

Fridjonsson, O., H. Watzlawick, A. Gehweiler, T. Rohrhirsch and R. Mattes. 1999. Cloning of the gene encoding a novel thermostable $\alpha$-galactosidase from Thermus brockianus ITI360.
Appl. Environ. Microbiol. 65:3955-3963.

Garsoux, G., J. Lamotte, C. Gerday and G. Feller. 2004. Kinetic and structural optimization to catalysis at low temperatures in a psychrophilic cellulase from the Antarctic bacterium Pseudoalteromonas haloplanktis. Biochem. J. 384:247-253.

Gerday, C., M. Aittaleb, J. L. Arpigny, E. Baise, J. P. Chessa, G. Garsoux, I. Petrescu and G. Feller. 1997. Psychrophilic enzymes: a thermodynamic challenge. Biochim. Biophys. Acta 1342:119-131.

Ghazi, S., J. A. Rooke and H. Galbraith. 2003. Improvement of the nutritive value of soybean meal by protease and $\alpha$-galactosidase treatment in broiler cockerels and broiler chicks. Br. Poult. Sci. 44:410-418.

Ghorbani, G. R., R. Kowsar, M. Alikhani and A. Nikkhah. 2007. Soymilk as a novel milk replacer to stimulate early calf starter intake and reduce weaning age and costs. J. Dairy Sci. 90:5692-5697.

Goulas, T., A. Goulas, G. Tzortzis and G. R. Gibson. 2009. A novel $\alpha$-galactosidase from Bifidobacterium bifidum with transgalactosylating properties: gene molecular cloning and heterologous expression. Appl. Microbiol. Biotechnol. 82:471477.

Grieshop, C. M., C. T. Kadzere, G. M. Clapper, E. A. Flickinger, L. L. Bauer, R. L. Frazier and G. C. Fahey Jr. 2003. Chemical and nutritional characteristics of United States soybeans and soybean meals. J. Agric. Food Chem. 51:7684-7691.

Hasan, F., A. A. Shah and A. Hameed. 2006. Industrial applications of microbial lipases. Enzyme Microb. Technol. 39:235-251.

Hutadilok-Towatana, N., A. Painupong and P. Suntinanalert. 1999. Purification and characterization of an extracellular protease from alkaliphilic and thermophilic Bacillus sp. PS 719. J. Biosci. Bioeng. 87:581-587.

Ishiguro, M., S. Kaneko, A. Kuno, Y. Koyama, S. Yoshida, G. G. Park, Y. Sakakibara, I. Kusakabe and H. Kobayashi. 2001. Purification and characterization of the recombinant Thermus sp. T2 $\alpha$-galactosidase expressed in Escherichia coli. Appl. Environ. Microbiol. 67:1601-1606.

Iyo, A. H. and C. W. Forsberg. 1999. A cold-active glucanase from the ruminal bacterium Fibrobacter succinogenes S85. Appl. Environ. Microbiol. 65:995-998.

Kim, B. C., K. H. Lee, M. N. Kim, E. M. Kim, S. R. Min, H. S. Kim and K. S. Shin. 2009. Paenibacillus pini sp. nov., a cellulolytic bacterium isolated from the rhizosphere of pine tree. J. Microbiol. 47:699-704.

King, M. R., B. A. White, H. P. Blaschek, B. M. Chassy, R. I. Mackie and I. K. O. Cann. 2002. Purification and characterization of a thermostable $\alpha$-galactosidase from Thermoanaerobacterium polysaccharolyticum. J. Agric. Food Chem. 50:5676-5682.

Kohlmeier, R. H. 1990. World production, storage and utilization of various defatted animal and vegetable mid-high protein meals. In: World Conference of Edible Fats Oils Processing Basic Principles and Modern practices (Ed. D. R. Erikson). Am. Oil Chem. Soc. Champaign, IL, USA. p. 390.

Leder, S., W. Hartmeier and S. P. Marx. 1999. $\alpha$-galactosidase of Bifidobacterium adolescentis DSM 20083. Curr. Microbiol. 38:101-106.

Lei, X. G. and J. M. Porres. 2003. Phytase enzymology, 
applications and biotechnology. Biotechnol. Lett. 25:17871794.

Miller, G. L. 1959. Use of dinitrosalicyclic acid reagent for determination of reducing sugar. Anal. Chem. 31:426-428.

Patil, A. G. G., S. K. Praveen Kumar, V. H. Mulimani, Y. Veeranagouda and K. Lee. 2010. $\alpha$-galactosidase from Bacillus megaterium VHM1 and its application in removal of flatulence-causing factors from soymilk. J. Microbiol. Biotechnol. 20:1546-1554.

Roy, I., A. Gupta, S. K. Khare, V. S. Bisaria and M. N. Gupta 2003. Immobilization of xylan-degrading enzymes from Melanocarpus albomyces IIS 68 on the smart polymer Eudragit L-100. Appl. Microbiol. Biotechnol. 61:309-313.

Shipkowski, S. and J. E. Brenchley. 2005. Characterization of an unusual cold-active beta-glucosidase belonging to family 3 of the glycoside hydrolases from the psychrophilic isolate Paenibacillus sp. strain C7. Appl. Environ. Microbiol. 71:4225-4232.

Smiricky-Tjardes, M. R., C. M. Grieshop, E. A. Flickinger, L. L. Bauer and G. C. Fahey Jr. 2003. Dietary galactooligosaccharides affect ileal and total tract nutrient digestibility, ileal and fecal bacterial concentrations, and ileal fermentative characteristics of growing pigs. J. Anim. Sci. $81: 2535-2545$.

Smits, C. H. M. and G. Annison. 1996. Non-starch plant polysaccharides in broiler nutrition-towards a physiologically valid approach to their determination. World's Poult. Sci. J. 52:204-221.

Stein, H. H., L. L. Berger, J. K. Drackley, G. C. Fahey Jr, D. C. Hernot and C. M. Parsons. 2008. Nutrition properties and feeding values of soybeans and their coproducts. In: Soybeans, Chemistry, Production, Processing, and Utilization (Ed. A. Johnson, P. J. White and R. Galloway). AOCS press, Urbana, IL. USA. pp. 613-660.

Syed, D. G., D. Agasar and A. Pandey. 2009. Production and partial purification of $\alpha$-amylase from a novel isolate Streptomyces gulbargensis. J. Ind. Microbiol. Biotechnol. 36:189-194.

Tamura, K., J. Dudley, M. Nei and S. Kumar. 2007. MEGA4: Molecular evolution genetics analysis (MEGA) software version 4.0. Mol. Biol. Evol. 24:1596-1599.
Tamura, K., M. Nei and S. Kumar. 2004. Prospect for inferring very large phylogenies by using the neighbor-joining methods. Proc. Natl. Acad. Sci. USA. 101:11030-11035.

Thompson, J. D., D. G. Higgins and T. J. Gibson. 1994. CLUSTAL $\mathrm{W}$ : improving the sensitivity of progressive multiple sequence alignment through sequence weighting, position-specific gap penalties and weight matrix choice. Nucleic Acids Res. 22:4673-4680.

Viana, P. A., S. T. De Rezende, V. M. Marques, L. M. Trevizano, F. M. L. Passos, M. G. A. Oliveira, M. P. Bemquerer, J. S. Oliveira and V. M. Guimaraes. 2006. Extracellular $\alpha$-galactosidase from Debaryomyces hansenii UFV-1 and its use in the hydrolysis of raffinose oligosaccharides. J. Agric. Food Chem. 54:2385-2391.

Waeonukul, R., P. Pason, K. L. Kyu, K. Sakka, A. Kosugi, Y. Mori and K. Ratanakhanokchai. 2009. Cloning, sequencing, and expression of the gene encoding a multidomain endo-beta-1,4xylanase from Paenibacillus curdlanolyticus B-6, and characterization of the recombinant enzyme. J. Microbiol. Biotechnol. 19:277-285.

Wang, H., H. Luo, J. Li, Y. Bai, H. Huang, P. Shi, Y. Fan and B. Yao. 2010. An $\alpha$-galactosidase from an acidophilic Bispora sp. MEY-1 strain acts synergistically with $\beta$-mannase. Bioresour. Technol. 101:8376-8382.

Wang, Q. F., J. L. Miao, Y. H. Hou, Y. Ding, G. D. Wang and G. Y. Li. 2005. Purification and characterization of an extracellular cold-active serine protease from the psychrophilic bacterim Colwellia sp. NJ341. Biotechnol. Lett. 27:1195-1198.

Wang, Y., X. Gao, Q. Su, W. Wu and L. An. 2007. Cloning, expression, and enzyme characterization of an acid heat-stable phytase from Aspergillus fumigatus WY-2. Curr. Microbiol. 55:65-70.

William, G. W., M. B. Susan, A. P. Dale and J. L. David. 1991. 16S ribosomal DNA amplification for phylogenetic study. J. Bacteriol. 173:697-703.

Yoon, M. Y. and H. J. Hwang. 2008. Reduction of soybean oligosaccharides and properties of $\alpha$-D-galactosidase from Lactobacillus curvatus $\mathrm{R} 08$ and Leuconostoc mesenteriodes JK55. Food Microbiol. 25:815-823. 